\title{
Sociological Imagination for the Aged SOCIETY
}

\author{
MARINUs OsSEwaARde
}

Abstract. The aim of this article is to explore how the sociological imagination may generate new insights regarding the dangers and possibilities that arise when an old order disintegrates and a new one has to be created. The new order is theorized as the "aged society". The aged society is demarcated by radical population aging that also constitutes our main challenge, especially when coupled with globalization and new technological developments. In this article, the questions and challenges of the aged society, as an emergent world, are not perceived as purely financial, neuroscientific, biological, or technological ones, but as issues of freedom and reason. Contemplating the aged society, however tentative it might be since it regards social realities that are still becoming, might enable us to reconsider and reassess presuppositions of most current aging studies in terms of these values at risk.

Keywords: C. Wright Mills, sociological imagination, aged society, aging troubles, aging issues, social theoretic challenges.

Résumé. Le but de cet essai est d'explorer comment l'imagination sociologique peut générer de nouvelles connaissances concernant les dangers et possibilités qui surviennent quand un ancien ordre se désintègre et un nouveau ordre est en devenir. Ce nouvel ordre est théorisé comme "la société âgée". La société âgée est caractérisée par un radical vieillissement de la population. Ce fait, surtout dans le contexte de la mondialisation et des développements technologiques, est perçu comme notre défi principal. L'auteur conçoit les questions et les défis de la société âgée, un monde en devenir, non seulement comme étant d'ordre financier, neuroscientifique, biologique, ou technologique, mais surtout comme concernant la liberté et la raison. Dans de cadre de l'étude de la société âgée, qui ne peut être que circonspecte vu qu'elle concerne des réalités sociales en devenir, ces valeurs peuvent nous permettre de reconsidérer et de réévaluer les présuppositions de la plupart des études sur le vieillissement.

Mots-clés: la société âgée, biocratie, C. Wright Mills, condition post-mortelle, théorie sociale, transformations sociales, l'imagination sociologique 


\section{INTRODUCTION}

In the past two decades, several sociologists have pointed out that a new sociological imagination is needed for a new world. Ulrich Beck $(2000,134)$, for instance, notes how "we need a new sociological imagination which is sensitive to the concrete paradoxes and challenges of reflexive modernity and which at the same time is thoughtful and strong enough to open up the walls of abstraction in which the academic routines are captured." The new world, Beck observes, is characterized by worldwide crises and increased unsustainability of social institutions that belonged to bygone eras. As the new world is a global era, the new sociological imagination, says Gerard Delanty (2006), has to be a "cosmopolitan imagination". For Steve Fuller (2006) a "new sociological imagination" is needed to grasp the dynamics of the sixth industrial revolution in which nanotechnology, information technology, robotics, neurosciences and biotechnology are made to converge. Fuller $(2006,12)$ defines the contemporary epoch as the era of "bioliberalism", a condition in which biomedical sciences and industries are the ascendant mode of knowledge and production. By giving the concept of sociological imagination a central role in their thought, these sociologists, along with others, such as Louis Horowitz and Michael Burawoy, tread some way or the other in the footsteps of C. Wright Mills (Ossewaarde 2007). Indeed, the latter is known for having made recourse to this concept in a context (which Mills $(2000,166)$ calls "the postmodern period" dominated by Cold War politics.

The above sociologists point out how new eras require new sociological imaginations. When an era comes to an end, a new sociological imagination is needed for outlining the relationships between biographies and social structure of a new epoch (Solis-Gadea 2005). The sociological imagination that generated Mills' social theory is therefore to a certain extent insufficient to contemplate our present world and dilemmas. In the present paper, the new era is demarcated by aging that also constitutes our main challenge, especially when coupled with globalization (in particular, global capitalism) and the sixth industrial revolution. Aging is a global phenomenon; the world is aging and this has a profound effect on economic growth, living stands and the shape of the world order in both rich and poor countries (Powell 2010; Howe and Jackson 2011, 22). By 2050, about one in five of all living human beings are sixty five plus (Leeson 2011, 75). However, while the cosmopolitan sociological imagination of Delanty might help us to imagine and create new border-crossing forms of solidarity or alternative global ways of living together, it does not take the sixth industrial revolution into account. 
More generally, sociologists have not fully explored the possibilities that Mills' concept of sociological imagination offers when it comes to aging. This is surprising, since diverse sociologists have drawn on his works to creatively and critically understand new social realities, as well as to rethink sociology and scientific research today in the era of global capitalism (Burawoy 2005; Ossewaarde 2007 2011). Such engagement has, so far, not extended itself to the research on aging.

The aim of this article, therefore, is to explore how the sociological imagination may generate new insights regarding the dangers and possibilities that arise when an old order disintegrates and a new one has to be created. Thereby, the observation that "the postmodern period" that Mills observed in the 1950s, a post-industrial society characterized by a liberal welfare state emerging during the Cold War, is rapidly and irrevocably changing. That society as we have come to know it in the past six decades is turning into what recently has been labelled as an "aged society" (Hirayama 2010; Howe and Jackson 2011, 22). The label of the aged society is endorsed to emphasize that a new type of society or era, which is shaped by unprecedented demographic developments, is in the making. Within less than four decades, it is highly probable that over a third of the population in advanced industrial nations will be sixty five plus years, among whom more than 20 percent is expected to be eighty plus years. The prediction is that the number of centenarians will rapidly increase: it is forecasted that in advanced industrial nations one in three of those born in the $21^{\text {st }}$ century will become a centenarian. This new condition calls for new sociological imagination, for new sociological theorizing.

In the aged society, the age structure, the unprecedented scope and speed of aging processes, affects all social phenomena, including war and peace, political upheavals, university reforms, democracy, political parties, families, entrepreneurship, quality of work, youth unemployment, migrations, and so forth (Howe and Jackson 2011, 20). The particular age structure of the aged society, it is argued in this paper, is not good or evil in itself; the issue of the aged society is the ability of social structures to transform and accommodate radical changes in age structures (Leeson 2011, 80). What is resisted, in the present paper, is the tendency to think about the aging issue within the social structures of a near bygone era, that is, within the institutional framework of the Western welfare state that is subject to reform. In other words, an attempt is made to understand the novelty of a new era marked and defined by a new age structure and the corresponding definite disintegration of institutions and the values that such institutions transmit. The questions and challenges of the emergent world are not perceived as purely demographic, finan- 
cial, neuroscientific, biological, or technological ones, but, in the spirit of C. Wright Mills, as issues of reason and freedom. Contemplating the aged society as a new era in the making, however tentative it might be since it regards social realities that are still becoming, might enable us to reconsider and reassess presuppositions of most current aging studies.

\section{The Advent of a New Era}

The new demographic composition that characterizes an aged society certainly has important social implications. The decreasing birth rates and higher life expectancies in the second half of the twentieth century imply a decline in workforce and a rise in the ratio non-working/working in the twenty-first century. This further means that the institutional foundations and legitimacies of the post-industrial society as it had developed during the Cold War era are increasingly challenged. Lower tax revenues and higher welfare costs are the major elements that make up the gloomy picture of the aged society. The discourses about aging have therefore also predominantly been about these two factors, which until recently have more or less maintained a particular social system. In the various scenarios to get out of the above spiral, certain "facts", assumptions, and attributed powers are left largely undisputed. Hence, there seems to be hardly any doubt that biomedical and technosciences offer the solution to most "problems" (such as the dramatic increase in amount of dementia patients) related to aging and the aged society; or, that longevity is something to be achieved, as a cultural ideal. A few decades earlier, Ivan Illich $(1994,11)$ already noted the blurring of the boundaries between life and death when he warned for a "new biocracy", in which the desire to "postpone death at almost any cost" becomes the primary motive of social organization." More recently, Céline Lafontaine (2009) has noted how contemporary people seem to be living or believing in the era of the "postmortal condition" - a condition in which life, and being kept alive, is perceived as a higher good than the world of reason and freedom.

Though not all (forecast) studies on aging endorse such postmortalistic optimism or belief, there is a definite, even if unconscious, tendency to accept a particular social organization as perennial. Such collective unconsciousness follows from a lacuna in aging research that has been pointed out by several scholars, namely, that of a lack of social theory or contemplation and a superabundance of data (Powell and Longino 2002, 219). Similarly, Jeff Levin et al. $(2011,390)$ note that "as a whole, the field of empirical research on [...] aging has suffered from several problems, including a conceptual focus and limited familiarity with the real- 
world context." Jason Powell $(2009,67)$ observes that, without being encouraged and channeled by some social theory, aging research runs the risk of mindlessness, of amounting to "little more than a pile of bricks awaiting an architect." Perhaps even worse, without social theory, aging research runs the risk of serving particular interests, of reinforcing certain powers, and correspondingly of being both blind to hidden dangers and smothering alternatives yet unthought-of, which are, in the end, the fruits of mindlessness. Powell himself has turned to Michel Foucault's social theory, which enables him to discern power relations organized around the conceptualization or formulation of aging issues and the responses (such as policy measures) to the formulated problems. Critical gerontologists, similarly to Frankfurt School scholars like Max Horkheimer, Theodor Adorno, Herbert Marcuse, Jürgen Habermas and Axel Honneth, draw on critical theory to point at new forms of domination and liberation, and to point at social alternatives as contrasted with existing realities (Moody 2008).

The intellectual contributions of these social theoretic scholars are refreshingly insightful and go far deeper than scientific analyses in terms of demographic changes, financial balances that have to be maintained and escalating health expenditures that are to be financed. Foucauldian theorists and critical theorists rightly point out that issues around aging are not solely of a medical or economic nature; they have uncovered certain hidden processes, either in terms of new elites, power relations between professionals and the elderly, or "ageism" and an entire anti-aging industry. However, these social theories generally do not include the idea of the aged society as a new era. The question of whether the aged society that is already becoming marks a new era or not is relevant because it determines whether a new sociological imagination - and hence a new social theory - is necessary or not. The demographic composition of the aged society is unprecedented, which not only has economic implications but also cultural and political consequences. For instance, though "intergenerational" tensions are of all times, they have never been as tangible as in the last few years, when youngsters are confronted with what has been labelled "negative mobility" or "downward mobility" and a lugubrious future (Bauman 2012). Social cohesion or solidarity, though never self-evident, runs the risk of being undermined. Perhaps even more pertinently this solidarity may have to be redefined, in novel terms that transcend given, and perhaps outdated, frameworks. In industrializing societies, particularly in Africa and Asia, the intergenerational bond of the extended family system is disintegrating, damaging the traditional status of elderly people (Sabzwari and Azhar 2011; Apt 2012). In what Beck calls "reflexive modernity" that defines much of the Western 
nations today, intergenerational contracts of welfare systems are under pressure, as a post-war generation of baby boomers exit labour markets and come to heavily tax the resources of younger generations and the state (Silverstein, Conroy and Gans, 2012). In the aged society it is not only elderly care, but also the future prospects, the rights and duties, the possibilities of freedom and the risks of oppression of the younger generations that is at stake. The age structure of the aged society affects the social position for both the elderly and the young.

The novelty of the aged society to come makes a new sociological imagination that is able to discern unprecedented possibilities and dangers indispensable. In the post-war, cold-war period, nuclear technology, or more precisely, "technologists" and technocrats, had the last word, and correspondingly made world history in the name of security. Now it is in the name of "life" itself that a new world history is being made by new power elites. Enforced in contemporary bio-power relationships, "life" is typically defined as DNA, coded information, or as nano-machinery, that is, a biotechnical issue for bioengineers. The great merit of Mills is to have shown how there is a relationship between power elites, that is, those who occupy the top positions in society (in government, corporations and army), and world history; it is not blind fate, necessity, or evolution but the mindfulness or mindlessness of the power elites that determines the direction or shape of a new era. Hence the greatest threat to a worthwhile social existence, Mills explains, is mindlessness of power elites (which he also called "organized irresponsibility"), that is, the possibility of a worthwhile social existence depends on the mindfulness of power elites. Similarly, there is an intimate relationship between the self and the world, private issues and public issues, science and publics, the democratic commitment to the values of reason and freedom - European values that, Mills asserts, make it worthwhile to live together beyond the sheer necessities of human existence. The interrelatedness of so many seemingly separate features of social reality and the plurality of such connections can only be discerned through the sociological imagination. Mills $(2000,4-5)$ therefore also defines the sociological imagination as "a quality of mind", which the sociologist is deemed to possess or acquire. It is a specific intellectual capacity that enables the sociologist to grasp "the interplay of man and society, of biography and history, of self and world."

The sociological imagination, Mills $(2000,7)$ explains, enables sociologists to relate "the most impersonal and remote transformations to the most intimate features of the human self." In other words, he rejects the atomistic idea of the self and the empiricist idea that "facts" are "out there" and somehow speak for themselves. This is also the reason 
why Mills can be perceived as an ardent defender of social theories, and more specifically, of the uncovering of implicit and incomplete social theories that the sociologist endorses in the making and interpreting of "facts". The positivism and corresponding sociological unconsciousness that Mills was fighting, the public responsibility of sociology for the flourishing of reason and freedom - and the personal responsibility of the sociologist to uphold these values - that he pointed out, still form actual issues. The role of the sociologist, he held, is to find out how "the personal troubles of milieu" are related to "the public issues of social structure" (Mills 2000, 8). Personal troubles of "life" occur within individual biographies, and are experienced as private matters. Public issues, like the bioengineering and the management of the human species, are those related to the larger structures of social existence, like economic and political institutions. It requires the sociological imagination to show how personal troubles are actually public issues, how and by whom the latter are formulated, and how they affect individual lives. In other words, the sociologist is then able to see the overlapping and interpenetration of milieus, and how structural transformations (like the coming of the aged society) affect individual biographies.

Mills' concept of the sociological imagination resists the positivist belief that social theory is an unnecessary bias or surplus to scientific research, and instead rearticulates the suppressed idea that sociological insights, the quality or accuracy of scientific discoveries, of "facts", and of established relationships (correlation) depends on the quality of the mind and intellectual craftsmanship of the sociologist; and not only on the scientist's creation of "data" and appropriate methods (instruments). The claim that social reality can be understood or explained without any social theory is in fact an advocacy for unconsciousness and the blind play of ideologies and technologies. Indeed, for Mills, sociology and hence the sociologist serve reason and freedom, which also implies that any social theory and any genuine sociology has to embody and express these same values. A "value-irrelevant" social theory, if such type of contemplation is claimed to be, is for him one that can only serve hidden interests (like career interests and ideological interests) and be potentially reifying a status quo. Freedom, for Mills $(2000,174)$, is the freedom to formulate alternative futures: the birth of a new era does not mean that a new type of living-together, a new history, is pre-given or necessary. This is why (social) scientists, power elites, and citizens, that is, historymakers, are meant to cultivate the reason necessary to envision and give shape to a democratic future that in turn can safeguard the very values that have made it possible, namely, freedom and reason. Reason, in Mills' thought, is the cultivated intellectual capacity that enables critical 
and creative thinking, which can further inform and enlarge the scope of political speech, dialogue, decisions and actions.

\section{Theorizing the Aged Society}

To embrace a Millsian type of social theory is to be constantly aware of how history, including the new coming era, is being made and by whom. The advent of a new historical epoch like the aged society entails destruction and re-creation. Social theory enables sociologists to grasp both the process of destruction and that of re-creation; it enables them to grasp the historical distinctiveness of an era, to recognize structural transformations, and to formulate the tendencies and contours of the new era in comparison with other epochs. Mills classified his own era of the 1950s as the "post-modern period". For him, this new historical period was primarily shaped by nuclear physicists, with nuclear physics being the predominant science. The atom bomb inaugurated a new era marked by the technical possibility of annihilating the whole humankind. This is also the reason why Mills considered his new epoch as "post-modern": similar to Max Horkheimer and Theodor Adorno, Karl Jaspers and Arnold Gehlen before him, he saw how the Enlightenment assumption that scientific and technological advancement would lead to increased freedom has been proven to be untrue in the Cold War era. The technomilitary victory over enemies could hardly be called progress. In that post-modern period, science, technology, politics, and military power joined forces, forming a fearsome elite partnership. The Enlightenment movement that had been a counterforce to totalitarian tendencies in the modern era had been reduced to technocratic interventions, creating a bureaucratic world of "rationality without reason". And the ideologies of the Enlightenment movement - liberalism in the Western bloc and socialism or communism in the Eastern bloc - legitimized that bureaucratic world without reason.

A social theory about an epoch that is emerging is somewhat more challenging than critically understanding the era we currently live through, though there is an element of foresight involved in the latter case too. A new sociological imagination enables one to grasp the distinctive social structure of the aged society and the processes that are creating it (including globalization and bio-industrialization). In newness of the new era is radical and constitutes a sharp contrast with the post-industrial societies that have developed during the Cold War era. Post-industrial societies were, among other things, characterized by a declining workforce, that is, a higher dependency rate and lower birth 
rate. Typically between $7 \%$ and $14 \%$ of the population was above sixty five years old and birth-rates fell below the replacement fertility rate of 2.1 births per woman. The aged society, by contrast, refers to a situation in which $14 \%$ or more of a population is over sixty five and birth-rates are (typically far) below the replacement fertility rate (Van der Steen 2008). Japan is currently the most developed aged society, with $23 \%$ of its population over sixty five and a fertility rate of 1.2 in 2010 (Hirayama 2010). In 2012, more than 30 million Japanese people are over sixty five, in a shrinking Japanese population of 127.5 million. In gerontological forecast studies it is predicted that in 2050 more than a third of Japan's population will be over sixty five years, including a large amount of centenarians. Such is the historically unprecedented pattern of the new era.

Many nations - in particular South Korea, China, India, Pakistan, Brazil, Mexico, Cuba, Iran, Germany, Italy, Spain, Portugal and Greece - follow the demographic pattern of the aged society (OECD Factbook 2010, Powell 2010). Although there are large differences across nations in both the speed of aging and the current state of aging processes they are in, and political decisions, policies and state structure affect the outcomes of aging processes (Kapteyn 2010), it can be said that almost all nations come to face the radically new social context of the aged society. In South Korea, fertility rates have, within one generation, dropped from 3 in 1975 to just over 1 in 2000 (Leeson 2011, 76). In Iran, it is expected that more than a quarter of the population will be over sixty five in 2050, as contrasted with less than $7 \%$ in 2010 . In 1950, hardly $3 \%$ of the population was over sixty five in Mexico and Brazil, while by 2050 it is predicted that some $23 \%$ will be aged sixty five and over. In Cuba, it is predicted that $31 \%$ will be over sixty five by 2050 (Leeson 2011, 79). Only in African societies, the impact of the coming era will not be as dramatic as elsewhere. Africa's population is young and characterized by high fertility $(5,14)$ (Apt 2012, 94). Yet, also in Africa there is increased awareness of the coming demographic revolution and the need to develop new systems of elderly care outside the extended family system. Eleven African states provide pensions (Apt, 2012, 94 -101). By $2050,7.1 \%$ of the population will be over sixty five years in Africa, while today it is less than $4 \%$ (Kapteyn 2010).

The aged society, then, is characterized by a historically unprecedented increase in the number of elderly people living in society and low fertility rates (far below replacement levels of 2.1). A radically and speedily transforming age structure comes to affect all social phenomena, from wars to universities, necessitating a radical re-imagining of the social condition and the possibilities for thought and action (Howe and Jackson 2011,20). The aged society generates new challenges to 
the values of reason and freedom, which sociologists, as Mills insists, are called to defend if they are to live up to their vocational responsibilities. These challenges are largely overlooked in current gerontological researches that primarily predict the unsustainable financial burden that is to be expected from a shrinking workforce and rise of pensioners. It is pointed out how the aged society, as the current Japanese experience shows, is a new epoch in which the workforce shrinks, resulting in lower economic growth or negative growth and less innovation. In the Japanese aging society, for instance, the working age population rose from 50 million in 1950 to 75 million in 1975 and reached its peak of 87 million. Since 1995, the Japanese working population has been shrinking with about $1 \%$ per year, which is a typical pattern for the aged society. It is forecasted that the Japanese workforce will drop below 67 million by 2030. It is expected that in nations like South Korea, China, Brazil, Germany and Italy, working-age populations will decline even faster than in Japan (Davoudi et al. 2010). As the workforce declines, the financial sustainability of policy systems belonging to the era of post-industrial societies (the historically specific technical and financial arrangements, traditions, intergenerational solidarities and national identities underlying health care, education, pensions, etc.) is affected. In Japan, one person aged sixty five plus years was supported by eleven workers in 1960; it is forecasted that by 2030 one person aged sixty five plus years will be supported by only two workers (Muramatsu and Akiyama 2011). Public expenditure rises while public revenues from income tax decline. In Japan, social security expenditure reached $24.4 \%$ of the national income in 2010, more than four times the figure in 1970. Benefits for the elderly account for some $70 \%$ of that amount (EIU 2010). Such is the predictable pattern of an aged society in its early phases.

It is precisely this expected pattern that makes the aged society a fearsome, burdensome prospective reality for those who defend the institutions that had developed during the Cold War era. British Prime Minister David Cameron, for instance, has, like many other political elites, recently spoken of a "national crisis" for the UK, with regard to aging-related rising amount of dementia patients (The Guardian 2012b). Vladimir Putin has made the Russian population decline (without political interventions, Russia's population is expected to drop from $142 \mathrm{~m}$ in 2010 to $107 \mathrm{~m}$ by 2050 ) a top priority for the Russian state (The Telegraph 2012). The so-called "demographic burden hypothesis", that is, the belief that "undoubtedly, the burden will become much heavier for the next working-age generation" (Lin 2010, 151) dominates gerontological research and social policy today (Harper 2006, 21, 2010, 184; Van der Steen 2008). It is a hypothesis that is motivated by the incapacity to bear 
the disintegration of key, cherished, institutions that belonged to the previous era. In other words, it expresses the incapacity to recognize (and accept) the destruction that precedes the creation of a new era. Hence, in gerontological discourses, aging is synonymous with decline, such as heavier financial burden, deterioration, chronic illness, mass dementia, euthanasia, loss of productivity, lowered quality of work, stigma, powerlessness, and stagnancy (Kellehear 2007). The "demographic burden hypothesis" guides a predominantly "empty empiricist", to use Mills' words, type of gerontological research; such research is theory-empty and data-rich. Empiricist gerontological research - as well as power elites who rely on its conclusions - remain trapped in an old framework, while denying being in any framework at all; this is the price of the unconsciousness that Mills so fiercely criticized. To recall once again, the latter repeatedly notes how the first responsibility of the social scientist is to develop self-consciousness, and hence to critically and continuously evaluate the social theory underlying his (her) claims or perspectives. This means a reflexive reconsideration of the presuppositions used in research, and in the case of the aged society, a re-description and reassessment of taken-for-granted "facts" and conclusions. New questions, new concepts, and accordingly, new explanations and interpretations of the agedness are possible. In sum, theorizing the aged society as a new era may encourage radically new sociological pathways.

The lack of social theory or the denial of the necessity of any theory means that such gerontological research fails to take the novelty of the era into account, which also implies that it fails to envision alternative institutions, their possibilities, their emergence, or traces of becoming. It similarly fails to perceive, and warn for, the dangers that stem from the crumbling of institutions and from the vacuum that arises between destruction and re-creation. In the aged society, the institutional foundations of the post-industrial society are irreversibly undermined (Harper 2006, 26) - a structural transformation that cannot be halted by raising the retirement age or by privatizing health care. Japan provides us with some early illustrations of how the institutions of the post-industrial society are slowly crushed under the weight of the new demographic pressures of the aged society. Sheldon Garon (2010, 317-319) observes, for instance, that post-industrial Japan had its own historically distinctive family structure, namely, one in which the family rested on the woman's capacity as household manager and mother while men typically had jobs outside the family owned home. In Japan's aged society this institution is no longer self-evident as the number of unmarried people rapidly increases and home ownership becomes less accessible due to changes in the labour market with the corresponding economic instabilities (Suzuki 
et al. 2010, 525; Hirayama 2010, 176). New patterns in Japan's aged society are those of married and non-married adults living with their parents because they cannot afford an own house or household. Many are without full-time jobs and live off their parents' pensions. As Naoko Muramatsu and Hiroko Akiyama $(2011,429)$ note, in the aged society, "young adults are more likely to be worse off, stay single, and have even fewer children than their parents." In China, there is also a new family structure in the making, mainly due to the state's one-child policy and low fertility rates. It is envisioned that in the situation of a married couple, one child becomes responsible for supporting two elderly parents and four grandparents. Yet, due to the one-child policy, marriage is not within reach for a significant amount of men: as China has about $16 \%$ more boys than girls, millions of men have to live with the prospect of being "unmarriageable". In other words, the aged society tends to be characterized by radically new future prospects for the younger generations in terms of family life and/or expectations of social mobility.

Since the aged society is becoming or is being made, its troubles and issues are essentially undetermined and uncertain. This embryonic world is a playground for the exercise of power and for creativity in general. The future social structure, the type of public issue, and the nature and extent of personal troubles will largely depend on the imagination and decision of power elites, though "citizens", - however limited their number might be in the new era - and other socially engaged may also establish unthought-of institutions by choosing non-standard ways of living (like ecovillages), thereby resisting the dominance of particular institutions. It is still unclear, of course, whether political, academic, and scientific elites will dare to transcend the institutional framework - both in theory and practice - that belongs to an old era, and create enough space for creative thinking and action. In the next part, the tendencies in arguably highly important areas of personal and social existence will be examined, namely, the body and democracy.

\section{Reason and Freedom in the Aged Society}

Greater longevity and improved health, which is primarily the result of infrastructure, hygiene, use of fertilizers and insecticides, healthy lifestyles, and developments in medical science and biotechnology, in combination with lower fertility rates, which are mainly due to urbanization, decline of the extended family, abortion and the use of contraceptives, mean that a phase of life never previously seen in former historical eras comes to exist in the aged society. In this new demographic structure, the 
very meaning of the body, its living and its dying, is subject to changes in perception and in experience. Norbert Elias $(1985,6)$ notes how in ancient or pre-modern European societies, the personal trouble of the aging and decaying body was a shared, public issue. Suffering and death were part of social life, and though feared, were not aspects of life to be ashamed of, to be denied or hated. Christianity and more specifically, the promise of resurrection, and Christian culture generally certainly played a role in facilitating the confrontation. In modern and post-modern conditions, Elias notes how the irrevocable finitude of the body - that cannot survive decay and death - is concealed by "a strict social censorship" (Elias 1985, 40). In a similar sense, Hannah Arendt $(1958,2)$ refers to the wish "to escape the human condition." Anti-aging products (cosmetics, anti-wrinkle treatments, plastic surgery, Viagra, rejuvenation medicine, fitness cults, and so forth) are expressions of the modern endeavour to postpone and avoid the confrontation with the inevitable as much as possible (Fox 2005; Gilleard 2007; Coupland 2009). In the aged society, improved health and the rejuvenation bio-technologies have somewhat palliated this fear of the inevitable. As a result, the aging body is experienced in a different, more vital, way. Molecular technology is said to have the ability to reverse aging processes, and to postpone biological decline (Harper 2006, 30; Gray 2011, 215). "Life" becomes an idol and is fetishized (cf Illich 1994).

In other words, in the aged society, the aging body becomes more and more active: centenarians participate in physically demanding activities like marathon running and paragliding; the aging body is sexually active. Today, elderly people are the fastest-growing group in contracting sexually transmitted diseases (The Guardian 2012a). In Japan, the first aged society, adult films increasingly include sixty five plus porn actors (The Guardian 2011a). Many rock musicians from the baby boom youth culture of the 1960s are now rocking well in their seventies and eighties. In the media, these feats are highly praised; they are presented as the living proofs that aging need not be an obstacle to fully enjoying "life". Ironically enough, it is not aging but the victory over aging - and hence "eternal youth" - that is being celebrated. A disgust of decay is at work here, but the instruments to combat bodily decay are now much more sophisticated and apparently more efficient than ever before. This has led some scholars to rightly speak of "ageism". It is not aging as a natural phase of life that is being accepted and lived but the technical capacity to surmount aging. Hence, the sixth stage of human life - if one accepts the classification in terms of infancy, childhood, adolescence, youth, maturity, and old age seems to have given place to a prolongation of youth until death. Increasing longevity and rejuvenation were therefore also 
the political objectives of health policies in the post-industrial society. These active aging policies rested on the advices of medical power elites (health experts) who determined bodily needs and the necessary measures to achieve the desirable bio-political objectives through the willing co-operation of "life" idolizing subjects themselves. For "life" is the cultural icon.

In the aged society, these health experts now work with other experts (neuroscientists, biologists, technicians, and other hybrid forms of scientists) to a similar end - largely acclaimed as a praiseworthy one - of supporting a constant work of self-modulation in relation to politically and ideologically desired forms of aging (cf Powell 2009). These modulation and self-modulation have reached unprecedented peaks in the aged society. The body can now be extensively reconfigured; we have reached the era of the programmable human-machine hybrid - a type of "cheerful robot" in the jargon of Mills $(2000,171)$. In the 1960s, Erich Fromm $(1984,131)$ wrote in an essay on aging that "what we should avoid... is transforming the old person into the total consumer, making him into a person whom we teach how to pass away the time decently while he waits for his own passing - death." Almost five decades later, Kelly Joyce and Meika Loe $(2010,171)$ note how "old people are cyborgs in contemporary life, blending machine and biology in both their personal identities and their relations to the external world." These cautions and warnings are considered by some as "pessimistic", unfounded, or unnecessarily exaggerated fears. However, these voices are expressions of a trivialization of the issues that the new era - in which aging is bound less to biological life processes than to new biotechnologies and biomedical consumption - confronts us with. The legitimacy of claims has to be continuously examined; the questions of how aging biographies and history of the aged society are being made, and by whom have to be similarly posed, since the values of freedom and reason are here at stake. Hence, it means being aware of political and ideological purposes in the "life" project (Joyce and Loe 2010, 173; Williams, Higgs and Katz 2012). It means asking a very old question (c.f. Arendt 1958, 3 ) - is a high-tech body normal, desirable, or acceptable because it has been decided by a few elites? Or, is all that is possible also desirable? Such questions require delving into the sources of the new social norms that are required for the aged society, in order to help old and young to distinguish between freedom and despotism.

The question of freedom and despotism is not a personal one, but is (by definition) a political one. The aged society implies a different type of political existence, and the pregnant issue is whether a democratic existence can still be maintained. Many scholars, including Mills, have 
pointed out how the Cold War era was one in which democracy was not at its best, meaning that government tended to be technocratic, shaping a capitalist bloc more than a democratic society. Democracy was more procedural than substantive, more a system than a world of reason and freedom. Aging issues were primarily settled through the creation and enforcement of the so-called "intergenerational contract" (Metz 2002), through which the workforce provided for the retirees. This narrowed understanding and practice of politics also explains why the political concern in the new context of an aged society has primarily been about the disintegration of the same contract. The issue of democracy tends to be overlooked once again. The shrinking workforce and increased cutbacks from the same workforce in order to maintain entitlement levels of retirees (and other non-working recipients), that is, the demographic burden dominates political discourse. This discourse is firstly one on GDP decline, which follows from a workforce that shrinks faster than labour productivity rises; and secondly one on lack of innovation and entrepreneurship, which follows from a graying workforce (as Neil Howe and Richard Jackson $(2011,21)$ observe, older workers are typically less productive, less innovative and less entrepreneurial). This has also had as consequence austerity measures that try to rescue the "intergenerational contract", leading to more intergenerational inequalities and negative social mobility (cf Gilleard and Higgs 2009). Such responses to the crisis - typical for the intermediary period between destruction and re-creation - not only fail to imagine alternative institutions but are also destroying an already weak intergenerational solidarity by creating resentment.

Alfio Cerami $(2011,339)$ emphasizes that the aged society requires "a new politics of ageing". Such politics must create and enforce a new intergenerational contract, or rather, it must create the - democratic space necessary for new forms of social solidarities. This means that democratic politics, which Mills understands as the making of publics in which mindful citizens make the values of reason and freedom flourish in dialogues, has to be developed, which further excludes technocratism, bio-politics, populism and sectarianism. A restored political thinking and practice will also ward off an even subtler danger, namely that of a "gerontocracy". A rule of the elderly can only be legitimate if the elderly can be expected to be politically wiser and more prudent, as they were expected to be in pre-modern and non-European societies. Such a gerontocracy, if allowed to be, would mean the end of democracy. An elderly citizenry (Metz (2002, 325-326) stresses that in the aged society, fifty plus years voters and fifty plus years workers are a majority) would organize its collective interests, in the form of senior parties, senior unions 
and senior media against a minority of younger generations. The latter already feel uneasy about contemporary pension reforms, particularly as an increasing number of younger workers is doomed to be content with temporary jobs, lower incomes and limited (if any) pension entitlements. At the same time, strongly vested interests in various sectors (pensions and health care) continue to be maintained as if we are living in a previous era, and, as Illich rightly pointed out, it is taken for granted that health care entails skyrocketing status quo medical expenditures. The lack of imagination on all levels is, if we contemplate with Illich and Mills, breathtaking.

The disintegration of solidarities and the recourse to power - or entitlements - constitute a state of alienation from the aged society. In extreme cases, this implies that elderly or those who are highly dependent on others would no longer be able to count on the mercy of others, since there would be no living-together, no ties that would bind separate individuals left to their self-responsibilities. The reported cases of elderly deprivation, violation of human rights of senior citizens and pensioners living below the poverty line (including elderly starvation in Japan) (The Guardian 2011c), in combination with downward mobility and prospects of long-term unemployment and jobs below qualifications, skills and expectations for the younger generations, might well become the rule rather than exceptions, due to austerity and lack of growth. In European nations like Greece, Italy, Spain and Portugal, this combination of elderly deprivation (in each of these nations about one in five is over sixty five) and mass youth unemployment, forcing younger generations into global migration, is already an awkward reality. A "new politics of ageing" will fail to develop if the strongly institutionalized categories of thought, feeling and action - reifying categories that are historically specific for the post-industrial era - persist. Personal milieus would then become the objects of mindless, directionless forces (say, the technological determinisms of the sixth industrial revolution) that imperil the values of freedom and reason, which would further turn public issues - regarding the life and death of selves - into matters of preferences and power. A shrinking workforce typically implies manpower shortages that typically more investments in technology, to enhance labour productivity; and less investment in human beings and values like freedom and reason (Howe and Jackson 2011, 22). Jason Powell $(2009,674)$ warns how "the aging individual is [already] located in a political field saturated with power relations that render it docile and productive and thus useful." Mills (2000, 188) himself noted that the social structure of what was a young aging society in the making in the Western world, in the 1950s, was not an altogether democratic one, being devoid of intellectual and moral substance 
that a real democratic society requires. If the new (global) bio-liberal forces of the becoming era continue to penetrate personal milieus, and to determine the content of public issues, this would effectively mean the end of democratic society, that is, the end of freedom and reason.

\section{Concluding Remarks}

Goethe once said that "every fact is theory" (quoted in Jaspers 1967, 213), whereby it must be added that theory is not equivalent to bias or illusion, which is what an extreme positivism would like to make us believe. The demographic burden, as it appears in discourses about aging processes, and the aged society, is certainly a social fact, but only in relation to the theoretic assumptions that lead to such a conclusion. The demographic burden would be the only thing that can be said about the aged society if the welfare systems that characterized the previous era is claimed to be the only possibility for all eras to come, so that all means to sustain it can be justified. Zygmunt Bauman $(2005,307)$ notes how the fear of the demographic burden underlies technological development: the latter is expected to make the difference between "life" via biotechnological interventions or a slow and painful - "undignified" - death. Along this "biocratic" line, all bio-technological solutions (and all other scientific-technological-political cocktails) are to be welcomed if they are able to sustain the status quo, which also includes more subtle social dimensions like the disgust for decay (destruction) and the desire for eternal youth, associated with beauty. "Beautifully or gracefully aging" is also a term that appears in scientific reports. Though scholars have certainly questioned these culturally established standards of beauty, such critical thinking does not seem to have extended itself to power elites. If low fertility rates persist, increased longevity generated by biotechnological interventions will, of course, not stop population decline within nations. It is forecasted that by the end of the $21^{\text {st }}$ century, Japan's population will be halved. And it has been calculated that the very last Japanese baby will be born in the year 2959, assuming the Japan's current fertility rate continues unchanged (Howe and Jackson 2011).

Power elites and - hence also whole societies or "cultural constellations" - show reluctance to accept the novelty of the coming era labelled as the aged society, to accept the destruction of so many cherished institutions, including values like autonomy, emancipation and progress. Though such reluctance is far from being rational - or scientific - it is driving so many scientific, technological, and political endeavours. It is driving the sixth industrial revolution of the convergent technologies 
that is organized around the idol of "life". In the end, the latter promises a longer period of good health and labour productivity, expanding, as Steve Fuller $(2009,12)$ emphasizes, "the economy in general and deferring the need for individuals to draw on pensions." Reification follows from the incapacity to think of alternatives that value freedom and reason, that is, from a numbness of the mind. A new sociological imagination is therefore needed to transcend compulsive thinking and practices; the assumptions underlying aging researches and the premises have to be re-examined for the coming new era, to adapt to this new type of society, and to embrace the new social condition or at least come to terms with it in a reflexive and liberating manner. Sociology, as Mills understood it, cannot serve ideological and technological interests. Sociology is called to serve reason and freedom, and hence has to resist scientific orthodoxies and all other forms of status quo existence. Such unsettling of established knowledge regarding how a new age structure shapes a new social condition for thought and action creates new space to rethink, re-describe, and re-asses our present and future social processes. In the long-run, a new sociological imagination should enable us to discern alternative institutions and the values these may transmit, which may well be radically different from what we have been used to till now.

The creation of new institutions in the aged society might well require a truly cosmopolitan sociological imagination, perhaps in a slightly different sense than meant by Delanty, namely, a sociological imagination that is able to draw on sources from all ages and places. These diverse alternatives would enable us to evaluate our dominant and tenacious understandings of health, beauty, and solidarity, of pain and death. As Illich (1994) reminds us, in antiquity, health referred primarily to harmony and balance, while the present understanding of health is dominated by medical powers and rests on the assumption that pain is an evil that has to be fought at any price. Illich speaks of the cultural capacity for suffering; the very ability to cope with suffering without becoming dependent on technological myths is a sign of health. Fear of suffering, he notes, ultimately triggers cultural (and hence democratic) regress, or leads to what Mills called mindlessness. Theorizing along the lines of Mills and Illich makes it clear that what is at stake in the coming era is democracy itself. Scholars like Jean-Marie Guéhenno and Colin Crouch, have noted that, in the era of global capitalism, democracy, and hence freedom and reason, belongs to a bygone era. It is not people but giant firms that shape new worlds. Along this line of reasoning, the aged society is doomed to be regulated by mindless forces at the expense of what Mills called the publics of democratic society. If we are to remain mindful and free in the aged society, then the public issues of the aged 
society are to be resolved in democratic publics, therein aided by sociological imagination of the new era in the making, filled with hope more than despair, that Millsian social theory may provide.

\section{REFERENCES}

Apt, Nana Araba. 2012. Aging in Africa: Past experiences and strategic directions. Ageing International 37:93-103.

Arendt, Hannah. 1958. The Human Condition. London: The University of Chicago Press.

Baert, Patrick and Filipe Carreira da Silva. 2010. Social Theory in the Twentieth Century and Beyond. Cambridge: Polity Press.

Bauman, Zygmunt. 2005. Education in liquid modernity. Review of Education, Pedagogy, and Cultural Studies 27(4):303-317.

2012. Downward mobility is now a reality. The Guardian, 31 May.

Beck, Ulrich. 2000. World Risk Society. Cambridge: Polity Press.

Bloom, David E. and Roddy McKinnon. 2010. Social security and the challenge of demographic change. International Social Security Review 63(3):322 .

Burawoy, Michael. 2005. American Sociological Association presidential address: for public sociology. British Journal of Sociology 56(2):259-294.

Cerami, Alfio. 2011. Ageing and the politics of pension reforms in Central Europe, South-Eastern Europe and the Baltic States. International Journal of Social Welfare 20:331-343.

Cerutti, Furio. 2011. The deeper roots of legitimacy and its future. Review of International Political Economy 18(1):121-130.

Coupland, Justine. 2009 Time, the body and the reversibility of ageing: Commodifying the decade. Ageing \& Society 29:953-976.

Davoudi, Simin, Michelle Wishardt, and Ian Strange. 2010. The ageing of Europe: Demographic scenarios of Europe's futures. Futures 42(8):794-804.

Delanty, Gerard. 2006. The cosmopolitan imagination: Critical cosmopolitanism and social theory. British Journal of Sociology 57(1):25-47.

Elias, Norbert. 1985. The Loneliness of the Dying. Oxford: Basil Blackwell.

Fox, Nick J. 2005. Cultures of ageing in Thailand and Australia. (What can an ageing body do?) Sociology 39(3):481-498.

Fromm, Erich. 1984. The psychological problems of aging. Pp. 117-132 in Erich Fromm, On Disobedience and Other Essays. London: Routledge \& Kegan Paul.

Fuller, Steve. 2006. The New Sociological Imagination. London: Sage. 
2009. Knowledge politics and new converging technologies: A social epistemological perspective. Innovation: The European Journal of Social Science Research 22(1):7-34.

Garon, Sheldon. 2010. State and family in modern Japan: A historical perspective. Economy and Society 39(3):317-336.

Gehlen, Arnold. 1980. Man in the Age of Technology. New York: Columbia University Press.

Gilleard, Chris. 2007 Old age in ancient Greece: Narratives of desire, narratives of disgust. Journal of Aging Studies 21:81-92.

Gilleard, Chris and Paul Higgs. 2009. The power of silver: Age and identity politics in the $21^{\text {st }}$ century. Journal of Aging and Social Policy 21(3):277295.

Gray, John. 2011. The Immortalization Commission: Science and the Strange Quest to Cheat Death. London: Allen Lane.

Gullette, Margaret Morganroth. 2007. What exactly has age got to do with it? My life in critical age studies. Journal of Aging Studies 22:189-195.

Harper, Sarah. 2006. Mature societies: Planning for our future selves. Daedalus 135(1):20-31.

2010. The capacity of social security and health care institutions to adapt to an ageing world. International Social Security Review 63(3):177-196.

Hirayama, Yosuke. 2010. The role of home ownership in Japan's aged society. Journal of Housing and the Built Environment 25(2):175-191.

Howe, Neil and Richard Jackson. 2011. Global aging and the crisis of the 2020s. Current History 110:20-25.

Illich, Ivan. 1994. Brave new biocracy: Health care from womb to tomb. New Perspectives Quarterly 11(1):4-12.

Jaspers, Karl. 1967. The Future of Mankind. London: The University of Chicago Press.

Joyce, Kelly and Meika Loe. 2010. A sociological approach to ageing, technology and health. Sociology of Health \& Illness 32(2):171-180.

Kapteyn, Arie. 2010. What can we learn from (and about) global aging? Demography 47:191-209.

Kellehear, Allan. 2007. A Social History of Dying. Cambridge: Cambridge University Press.

Lafontaine, Celine. 2009. The postmortal condition: From the biomedical deconstruction of death to the extension of longevity. Science as Culture 18(3):297-312.

Leeson, George W. 2011. Prepared or not, Latin America faces the challenge of aging. Current History 110:75-80. 
Levin, Jeff, Linda M. Chatters, and Robert Joseph Taylor. 2011. Theory in religion, aging, and health: An overview. Journal of Religion and Health 50:389-406.

Levine, Donald N. 1985. The Flight from Ambiguity: Essays in Social and Cultural Theory. London: The University of Chicago Press.

Lin, Wan-I. 2010. The coming of an aged society in Taiwan: Issues and policies. Asian Social Work and Policy Review 4:148-162.

Metz, David. 2002. The politics of population ageing. The Political Quarterly 73(3):321-327.

Mills, C. Wright. 2000. The Sociological Imagination. Oxford: Oxford University Press.

Moody, Harry R. 2008. The maturing of critical gerontology. Journal of Aging Studies 22(2):205-210.

Muramatsu, Naoko and Hiroko Akiyama. 2011. Japan: Super-aging society preparing for the future. The Gerontologist 51(4):425-432.

Organization for Economic Cooperation and Development. 2010. OECD Factbook. www.oecd-ilibrary.org.

Ossewaarde, Marinus. 2007. Sociology back to the publics. Sociology 41(5):799812.

2011. The new welfare-warfare state: Challenges to the sociological imagination. Irish Journal of Sociology 19(1):132-149.

Pickard, Susan. 2009. Governing old age: The "case managed" older person. Sociology 43(1):67-84.

Powell, Jason L. 2009. Social theory, aging, and health and welfare professionals: A Foucauldian "toolkit." Journal of Applied Gerontology 29(6):669-682. 2010. The power of global aging. Ageing International 35:1-14.

Powell, Jason L. and Charles F. Longino, Jr. 2002. Postmodernism versus modernism: Rethinking theoretical tensions in social gerontology. Journal of Aging and Identity 7(4):219-226.

Sabzwari, Saniya R. and Gohar Azhar. 2011 Ageing in Pakistan: A new challenge. Ageing International 36(4):423-428.

Silverstein, Merril, Stephen J. Conroy, and Daphna Gans. 2012. Beyond solidarity, reciprocity and altruism: Moral capital as a unifying concept in intergenerational support for older people. Ageing and Society 32(7):12461263.

Solis-Gadea, Hector Raul. 2005. The new sociological imagination: Facing the challenges of a new millennium. International Journal of Politics Culture and Society 18(3/4):113-122.

Suzuki, Munenori, Midori Ito, Mitsunori Ishida, Norihiro Nihei, and Masao Maruyama. 2010. Individualizing Japan: searching for its origin in first modernity. British Journal of Sociology 61(3):513-539. 
Steen, Martijn van der. 2008. Ageing or silvering? Political debate about ageing in the Netherlands. Science and Public Policy 35(8):575-584.

Stockholm News. 2012. Prime Minister Fredrik Reinfeldt opens up for retirement age at 75.7 February.

Szinovacz, Maximiliane E. 2011. Introduction: The aging workforce: Challenges for societies, employers, and older workers. Journal of Aging and Social Policy 23(2):95-100.

The Guardian. 2011a. Japan's 77-year-old porn actor: Unlikely face of an ageing population. 21 October. 2011b. Man with an artificial heart. 30 October. 2011c. Care for elderly in 'absolute crisis', charity warns. 28 December. 2012a. Sex and the over-60s. 12 January. $2012 \mathrm{~b}$. Dementia research funding to more than double to $£ 66 \mathrm{~m}$ by 2015. 26 March.

The Telegraph. 2012. Vladimir Putin vows to reverse Russian population decline. 13 February.

Turner, Bryan S. 2006. Public intellectuals, globalization and the sociological calling: A reply to critics. British Journal of Sociology 56(3):345-351.

Williams, Simon J., Paul Higgs, and Stephen Katz. 2012. Neuroculture, active ageing and the 'older brain': Problems, promises and prospects. Sociology of Health \& Illness 34(1):64-78.

Marinus Ossewaarde is Associate Professor in Sociology of Governance, University of Twente, Netherlands. He is the author of Tocqueville's Moral and Political Thought: New Liberalism (London: Routledge, 2004) and Theorizing European Societies (Basingstoke: Palgrave Macmillan, 2013). He has published a variety of articles on topics like Europe, cultural movements, sovereignty, subsidiarity, cosmopolitanism, publics, dialectic and self-responsibility in journals like Current Sociology, Critical Sociology, European Journal of Social Theory, European Societies, Distinktion, Sociology and The European Legacy.

m.r.r.ossewaarde@utwente.nl 